\title{
13
}

\section{Component trade and China's regional economic integration}

Prema-Chandra Athukorala

International fragmentation of production—cross-border dispersion of component production/assembly within vertically integrated manufacturing industries-has been an important feature of the deepening structural interdependence of the world economy in recent decades. ${ }^{1}$ With a modest start in electronics and clothing industries in the late 1960s, international production networks have gradually evolved and spread into many industries such as sport footwear, automobiles, televisions and radio receivers, sewing machines, office equipment, electrical machinery, power and machine tools, cameras and watches. At the formative stage of product fragmentation, outsourcing predominantly involved locating small fragments of the production process in a low-cost country and reimporting the assembled components to be incorporated in the final product. Over time, production networks have begun to encompass many countries involved in the assembly process at different stages, resulting in multiple-border crossing of product fragments before getting incorporated in the final product. As the supply of parts and components through international networks became firmly rooted, producers in advanced countries began to move final assembly of an increasing range of consumer durables (for example, computers, cameras, television sets and motor cars) to overseas locations in order to be physically closer to their final users and/ or to take advantage of cheap labour.

There is a sizeable literature which points to the growing importance of fragmentation-based specialisation for China's dramatic economic transformation under market-oriented policy reforms over the past two decades (Borrus 1997 and 
1999, Naughton 1999, McKendrick et al. 2000, Brown and Linden 2005). However, the implications of China's increasing involvement in this new form of international specialisation for regional and global trade patterns have not yet been systematically examined. Much (if not all) of the literature on China's integration into the global economy and the perceived competitive threat to countries in the region is based on the traditional notion of horizontal specialisation scenario in which countries trade goods that are produced from start to finish in just one country (IMF 2004, Eichengreen et al. 2004, Ahearne et al. 2003, Lall and Albaladejo 2004). In a context where trade in parts and components (middle products) is growing rapidly, the standard trade flow analysis naturally runs the risk of ignoring complementarities in trade relations on the supply side. This is because intra/extra regional patterns of trade in parts and components and trade in related final goods (final trade) are unlikely to follow the same patterns.

The purpose of this paper is to assess the implications of China's evolving role in the process of international fragmentation of production for trade patterns in East Asia, based on a systematic separation of trade in parts and components from total trade flows using a new data set extracted from the UN trade database.

\section{Data}

The data for this paper are compiled from the UN Comtrade database based on the Revision 3 of the Standard International Trade Classification (SITC, Rev 3). The data relate to the eleven-year period from 1992 to 2003. The year 1992 was selected as the starting point because by this time countries accounting for over 95 per cent of total world manufacturing trade had adopted the new system. The analysis ends in 2003 which is the most recent year for which trade data are available for all reporting countries. Given the prohibitive cost of data covering the entire period, 1992, 1996 and 2003 are chosen for the inter-country/region comparison of trade patterns.

In its original form (SITC, Rev 1), the UN trade data reporting system did not provide for separating parts and components from final manufactured goods. The SITC Revision 2 introduced in the late 1970s (and implemented by most countries only in the early 1980s) adopted a more detailed commodity classification, which provided for separation of parts and components within the machinery and transport sector (SITC 7). There was, however, considerable overlap between some advancedstage assembly activities and related final goods within the sector in the Revision 2, making it difficult to separate fragmentation trade from total trade $(\mathrm{Ng}$ and Yeats $2001)^{2}$. Revision 3 introduced in the mid1980s marked a significant improvement 
over Revision 2. In addition to redressing overlaps within SITC 7, this new version of SITC provided for separation of parts and components trade in the 'miscellaneous goods' sector (SITC 8). These two sectors together accounted for around 70 per cent of total world manufacturing trade (defined as goods belonging to SITC 5 though 8 less SITC 68 (non-ferrous metals)) during the period under study.

SITC Revision 3, despite its significant improvement over the previous version, does not provide for the construction of data series covering the entire range of activities involving production fragmentation. Data reported under SITC 7 do provide a comprehensive coverage of fragmentation trade. But data for SITC 8 does not seem to capture fully fragmentation trade within that commodity category. For instance, for some products such as clothing, furniture, and leather products in which outsourcing is prevalent (and perhaps has been increasing), the related components are recorded under other SITC categorising (for example, pieces of textile, parts of furniture, parts of leather soles). The SITC data system does not provide adequate information to separate these components and relate them accurately to the related final product. Moreover, there is evidence that international production fragmentation has been spreading beyond SITC 7 and 8 to other areas, in particular pharmaceutical and chemical products (falling under SITC 5) and machine tools and various metal products (SITC 6). Assembly activities in software trade too have recorded impressive expansion in recent years. These are lumped together with 'special transactions' under SITC 9. So the movements of trade in parts and components reported used in this paper are presumably downward biased. These factors cause our estimates to be downward biased, and perhaps the degree of bias may have increased over the years with the gradual spread of production fragmentation to other areas of products beyond SITC 7 and 8 . The list of parts and components identified for these two sectors contains a total of 225 five-digit products-168 products belonging to SITC 7 and 57 belonging to SITC $8 .{ }^{3}$

East Asia is defined here to include the newly industrialised economies (NIEs) in North Asia (South Korea, Taiwan and Hong Kong), China and members of the Association of Southeast Asian Nations (ASEAN) Free Trade Area (AFTA). Among the AFTA member countries, only the six largest economies-Indonesia, Malaysia, the Philippines, Thailand, Singapore and Vietnam—are covered in the statistical analysis. Brunei, Cambodia, Laos and Myanmar are ignored because of lack of data. The UN data system does not cover Taiwan (because it is not a UN member). Vietnam has not yet started contributing to the UN trade data reporting system. Singapore has not been reporting data on its bilateral trade with Indonesia from 1964 onwards because of political reasons. In these cases data are extracted from partner-country records. 
The China Boom and its Discontents

ஜ 只 光

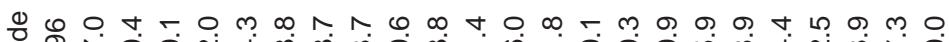
帝

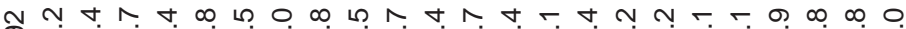

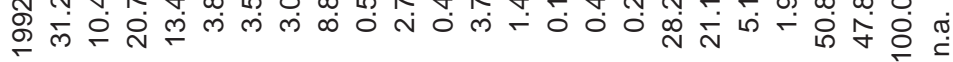

$m+\forall \infty \Pi \wedge N \forall 0$ m

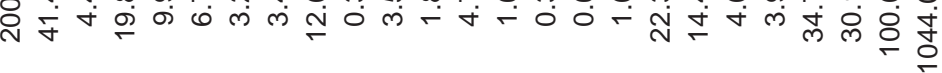

$\stackrel{\infty}{+}$

tे $\omega$ ก हू

மூ

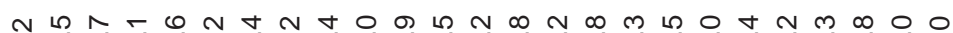
命

$m \infty \sim \pi)$

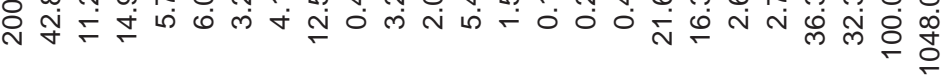

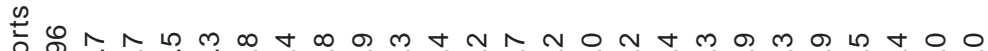
யூ̆

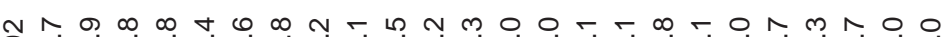
Љે

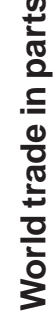

$\frac{\bar{m}}{\frac{\tilde{\omega}}{0}}$

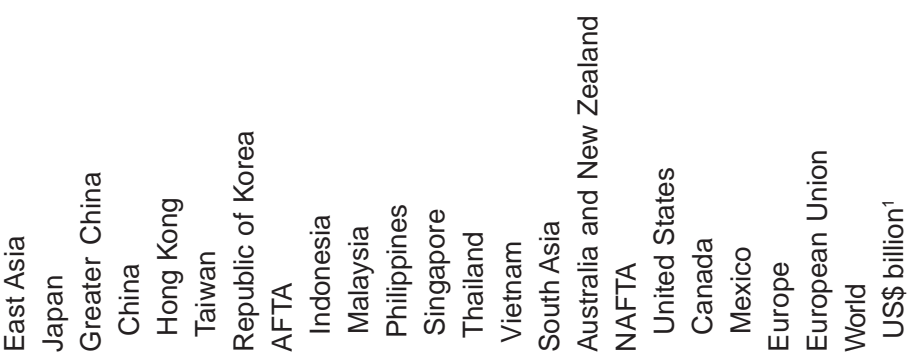




\section{Trends and patterns of trade in parts and components}

World trade in parts and components (henceforth referred to as 'components') increased from US $\$ 400$ billion in 1992 to over US $\$ 1000$ billion in 2003, recording an annual average growth rate of 3.7 per cent (Table 13.1). The share of these products in total world manufacturing trade increased from 17 per cent to 23 per cent between 1992 and 2003. Components accounted for one fourth of the total increment in world manufacturing trade between these two years.

The share of East Asia (including Japan) in total world exports of components increased persistently from 31 per cent in 1992 to 43 per cent in 2003. The corresponding increase on the import side was even faster, from 27.5 per cent to 41.4 per cent. In 1992, China was a small player in world component trade, with import and export shares smaller than most of the major trading nations in the region. However, China's trading position increased dramatically during the ensuing decade (Figure 13.1). In 2003, China's share in world import of components (9.9 per cent) was the largest among all countries in the region. The combined import and export shares of Greater China (China + Hong Kong + Taiwan) increased from 10.7 per cent to 19.8 per cent, and 7.8 per cent to 14.9 per cent respectively between 1992 and $2003^{4}$. Contrary to the popular perception of Greater China 'crowding out the rest', this increase has occurred against the backdrop of an overall increase in exports from other countries in the region.

The degree of dependence on this new form of international specialisation is proportionately larger in East Asia than in North America and Europe (and other regions in the world). In 2003, components accounted for 28 per cent of total manufacturing exports from developing East Asia, compared to the world average of 21 per cent, 25 per cent for the North American Free Trade Area (NAFTA) and 17 per cent for the European Union (EU) (Table 13.2). Of the total increment in manufactured exports from East Asia between 1992 and 2003, over a third came from component exports. The comparable figures for NAFTA and the EU were 26 per cent and 18 per cent per cent respectively. The share of components in China's manufacturing trade is still low by regional standards, but is growing fast. Between 1992 and 2003, the share of components in total manufacturing exports from China more than tripled (from 5.5 per cent to 15.2 per cent). On the import side, the increase was much faster, from 16.2 per cent to 33.5 per cent. Within East Asia, countries belonging to AFTA, in particular Malaysia, Philippines, Singapore and Thailand, stand out for their heavy dependence on production fragmentation for export dynamism. In 2003, components accounted for over 40 per cent of total manufacturing exports in AFTA, up from 24 per cent in 1992. 


\section{Figure 13.1 China's trade in parts and components}

(a) Value of parts and components, US\$ billion

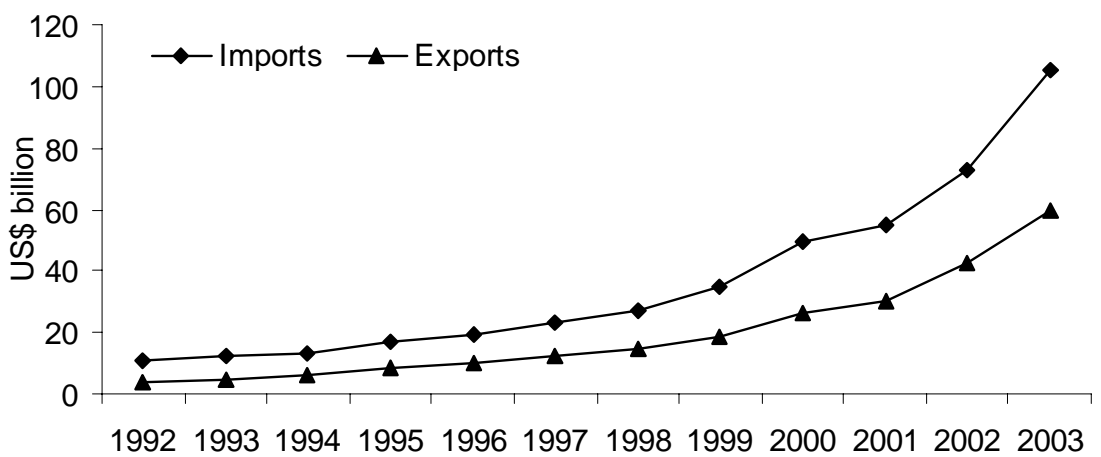

(b) Share of parts and components in China's manufacturing trade

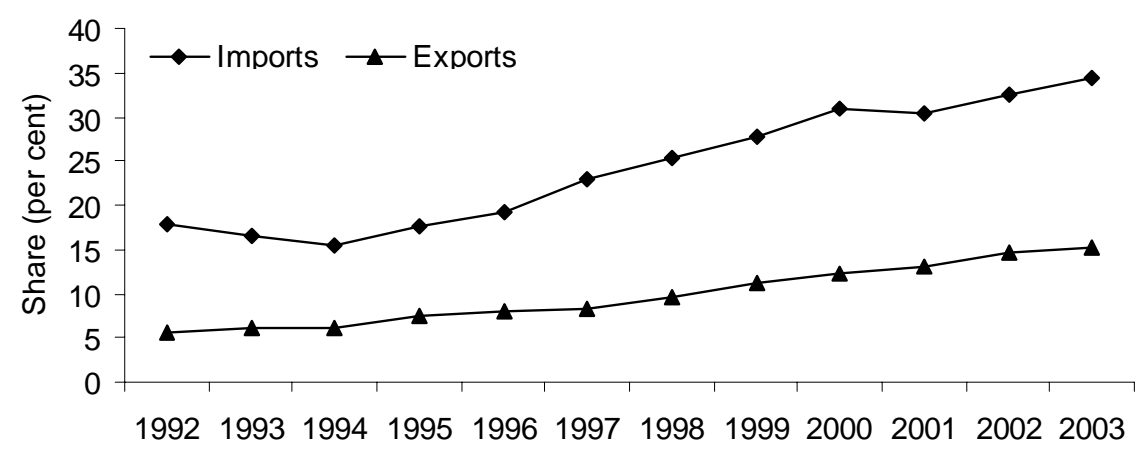

(c ) China's share in world trade in parts and components

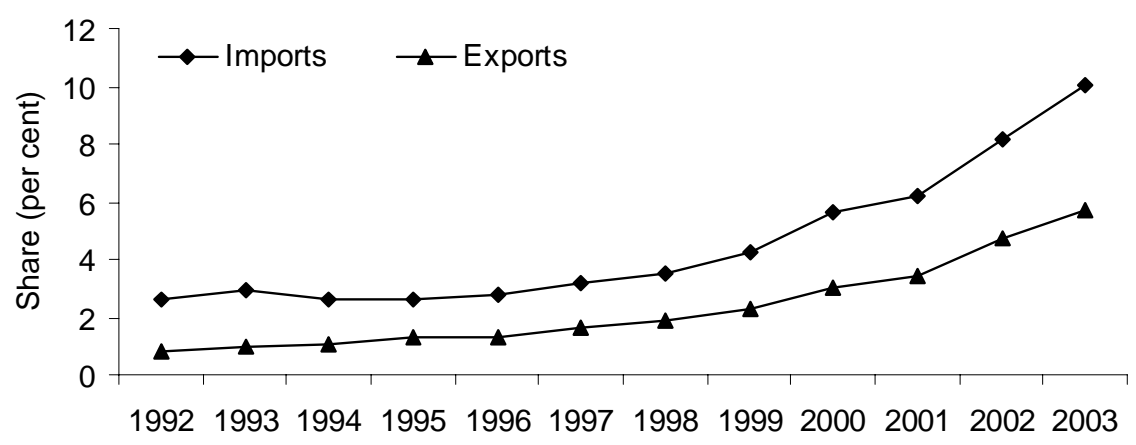

Source: Compiled from UN Comtrade Database. 


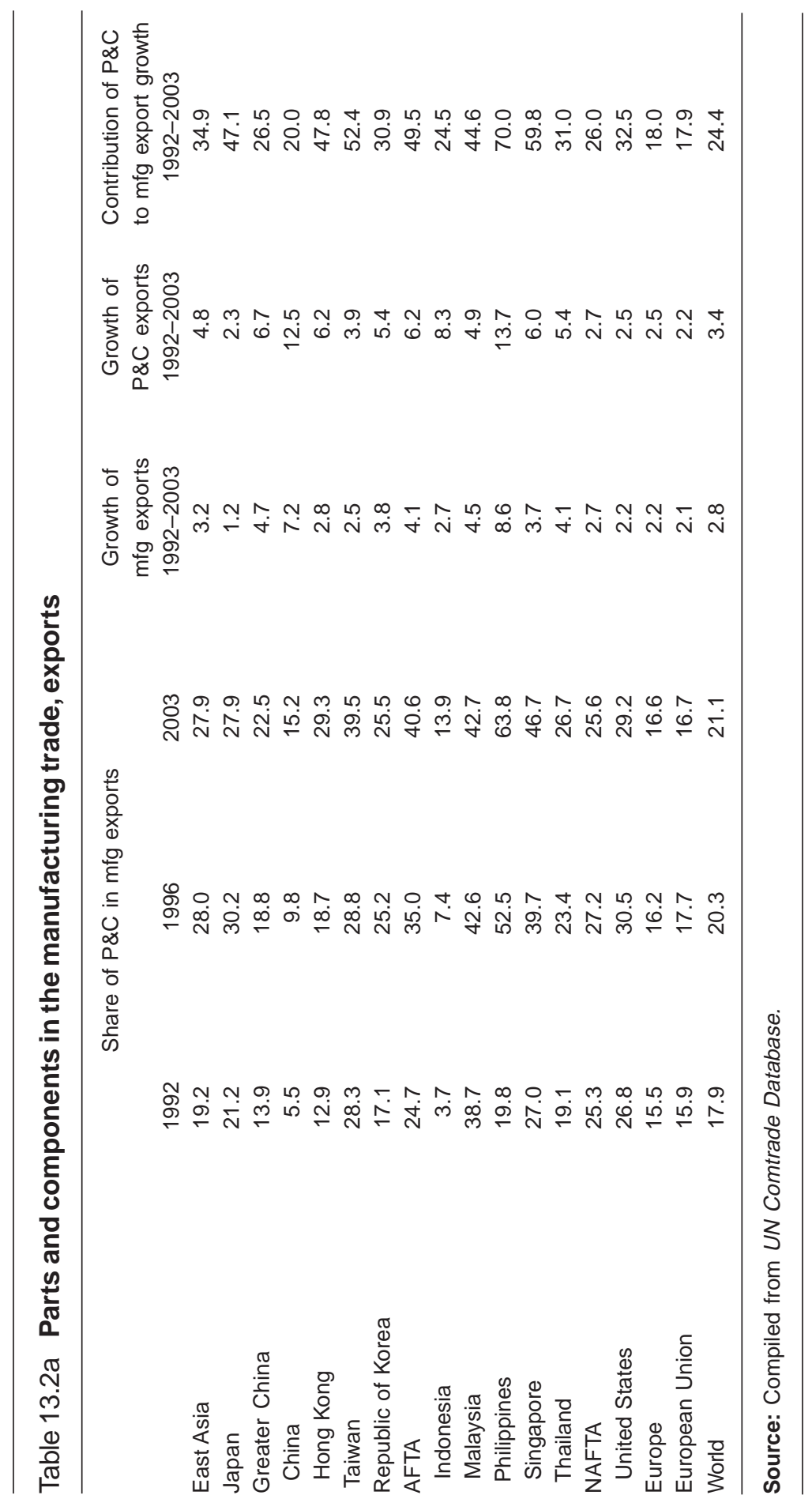




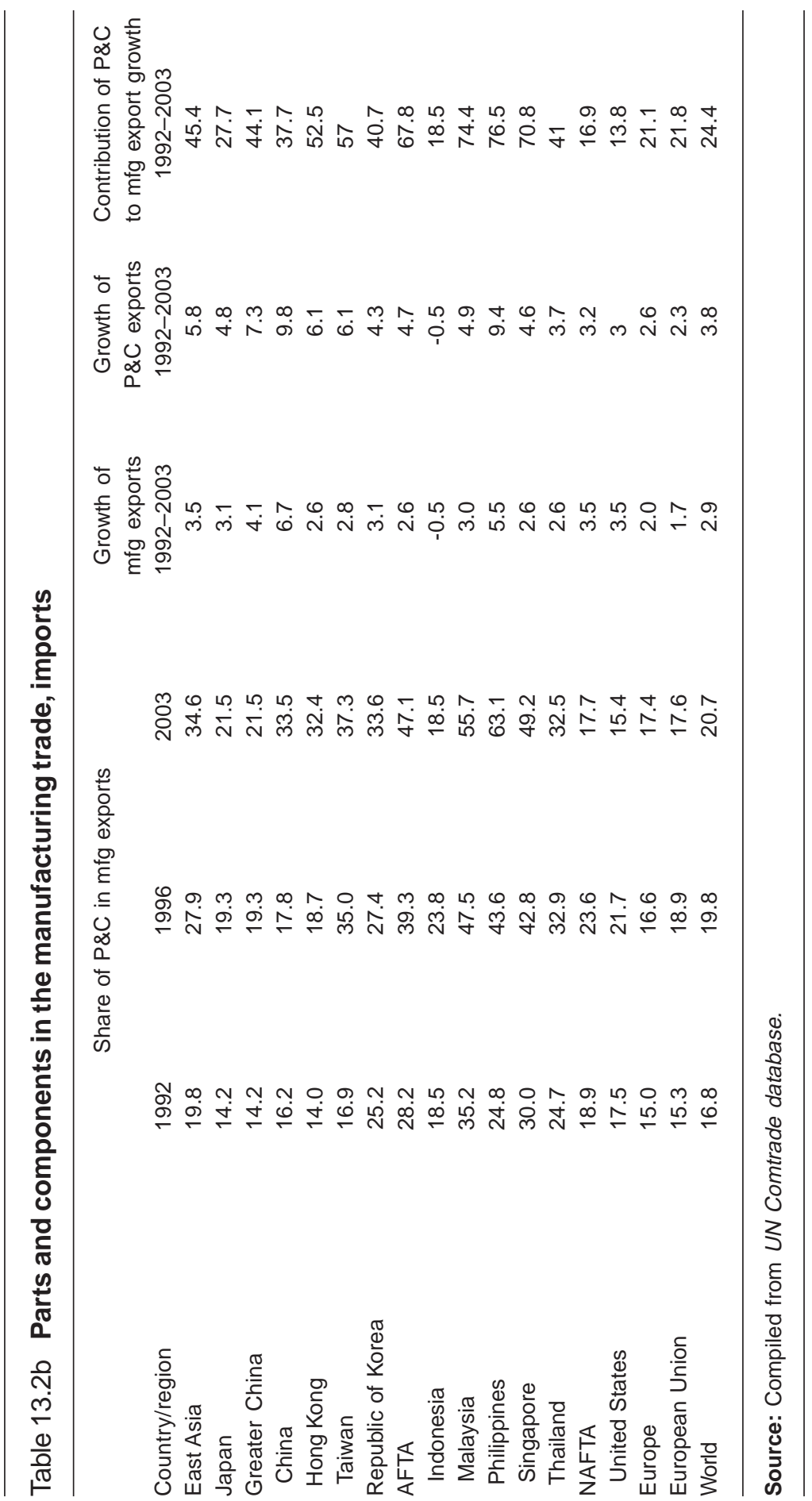


There is evidence that the formation of NAFTA and the integration of some of the new countries that emerged from the former Soviet Union with the rest of the Europe have set the stage for rapid expansion of international production networks in these regions (Kaminski and $\mathrm{Ng} 2005$, Kierzkowski 2001). Proximity to industrial countries and relatively low wages by regional standards (though not compared to some of the East Asian countries) are considered as added advantages of Mexico and countries in the European periphery compared to East Asian countries in this new form of international specialisation. However, interestingly, East Asia's preeminent position in fragmentation trade has remained remarkably resilient to the entry of these newcomers.

The explanation for the continued pre-eminence of East Asia seems to lie in powerful supply-side factors such as relatively more favourable trade and investment policy regimes which facilitate international production, better ports and communication systems that facilitate trade by reducing the cost of maintaining 'services links', and considerable inter-country wage differentials in the region, and the regional confluence of a large number of fast-growing countries which are at different stages of economic advancement (Jones et al. 2005, Athukorala and Yamashita 2005). Rapid economic expansion also seems to have brought about 'market thickness' (the economic depth of trading nations) which positively impacts on the location of outsourcing activity (Grossman and Helpman 2005). Part of the explanation also seems to lie in economic history-the early choice of the region (first Singapore and subsequently Malaysia and other countries) by multinational enterprises (MNEs) as a location of outsourcing activities. It is well known that there is a general tendency for MNE affiliates to become increasingly embedded in host countries the longer they are present there and the more favourable the overall investment climate of the host country becomes over time. Moreover, site selection decisions of MNEs operating in assembly activities are strongly influenced by the presence of other key market players in a given country or neighbouring countries (Rangan and Lawrence 1999). Against the backdrop of a long period of successful operation in the region, many MNEs (particularly United States-based MNEs) have significantly upgraded technical activities of their regional production networks in East Asia and assigned global production responsibilities to affiliates located in more mature countries (Singapore and Taiwan in particular, and also Malaysia in recent years) (Borrus 1997, Borrus et al. 2000).

Table 13.3 provides data on the composition of export and import flows of components. Both component exports and imports of East Asia are heavily concentrated in electronics and electrical industries. Semiconductors and other 
electronics components (components within SITC 77) alone accounted for more than half of component exports from East Asia in 2003. Adding to these items components of telecommunication equipment (SITC 76) and office and automated data processing machines (SITC 75) increases the concentration ratio to almost 90 per cent of total exports of components. The degree of concentration of component trade on electronics is much larger in AFTA (over 60 per cent) compared to the regional average and trade composition of China is much in line with that of the rest of developing East Asia. Electronic and electrical products are also the major areas of activity in NAFTA, EU and rest of the world. But trade patterns of these countries/regions are characterised by a greater presence of other items such as engines and motors (SITC 714), specialised industrial machinery (SITC 728), and internal combustion machines (SITC 713), for which transportation cost is presumably an important consideration for production location. In sum, China and East Asia are unique for the heavy concentration of parts and component trade in electronics.

\section{Fragmentation of production and regional trade patterns}

We have noted two important peculiarities of trade patterns in East Asia compared with total global trade and trade of European Union and NAFTA. First, component trade has played a much more important role in trade expansion in East Asia relative to the overall global experience and experiences of countries in other major regions. Second, China, in spite of late entry into this form of specialisation, has begun to replicate the overall regional patterns. In this section we proceed to examine intra-regional trade patterns in the region by explicitly taking into account these important developments in the regional economic landscape.

Table 13.4 compares the share of components in bilateral manufacturing trade flows of China with that of total East Asia and Japan. The share of components in intra-East Asian trade is much larger and it is growing faster than the region's extra regional trade. This share in intra-East Asian exports increased from 27.6 per cent in 1992 to 36.1 per cent in 2003, compared to a marginal increase from 26.8 per cent to 28.7 per cent in the region's total exports. On the import side, the share in intra-regional trade increased from 23.3 per cent in 1992 to 38.6 per cent in 2003. The corresponding increase on the import side was from 22.5 per cent to 35.7 per cent. The much larger difference in the share of components between intra and extra-regional exports compared to comparable figures on the import side reflects the greater reliance of the region on the rest of the world as a market for final goods. 


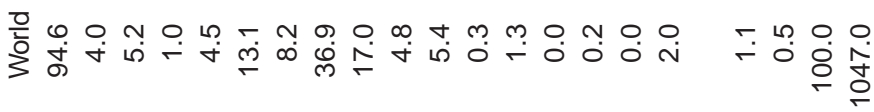

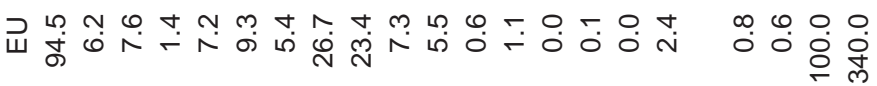

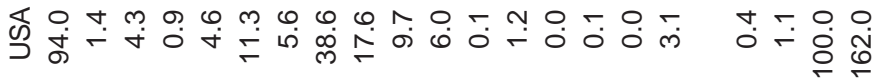

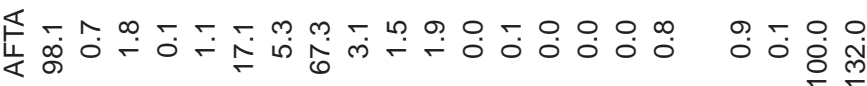

응

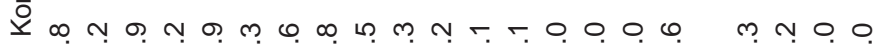

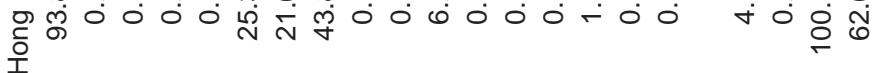

ఇ

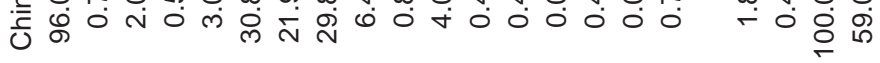

离 㐫品

Гٓ 复苟

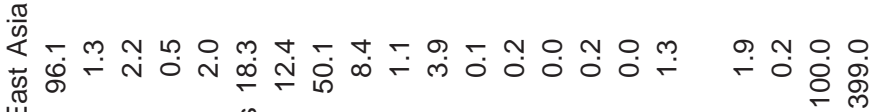
$\overrightarrow{\mathrm{c}}-\mathrm{W}$

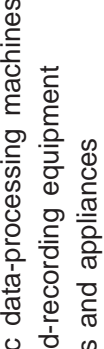

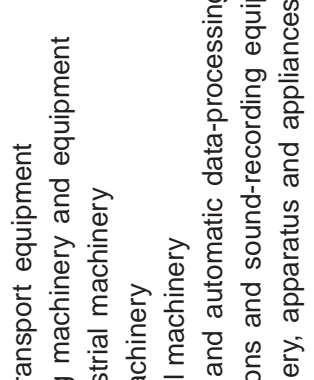

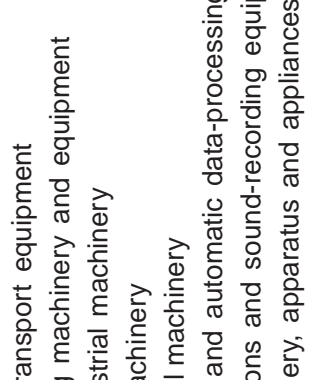

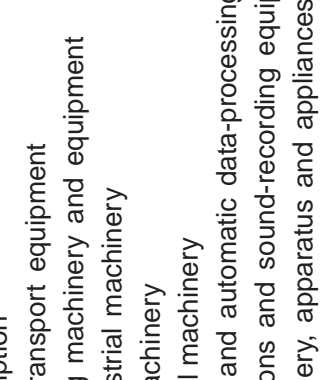

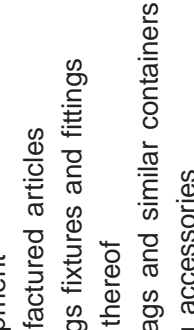

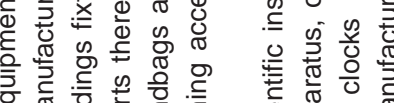

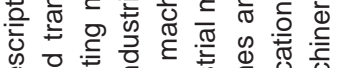

嵌

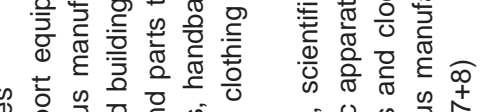

ब

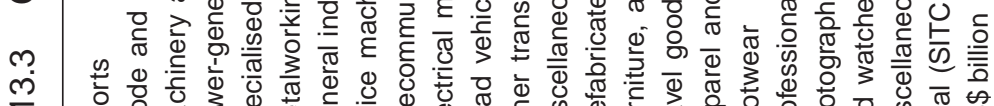



๘ 
Component trade and China's regional economic integration

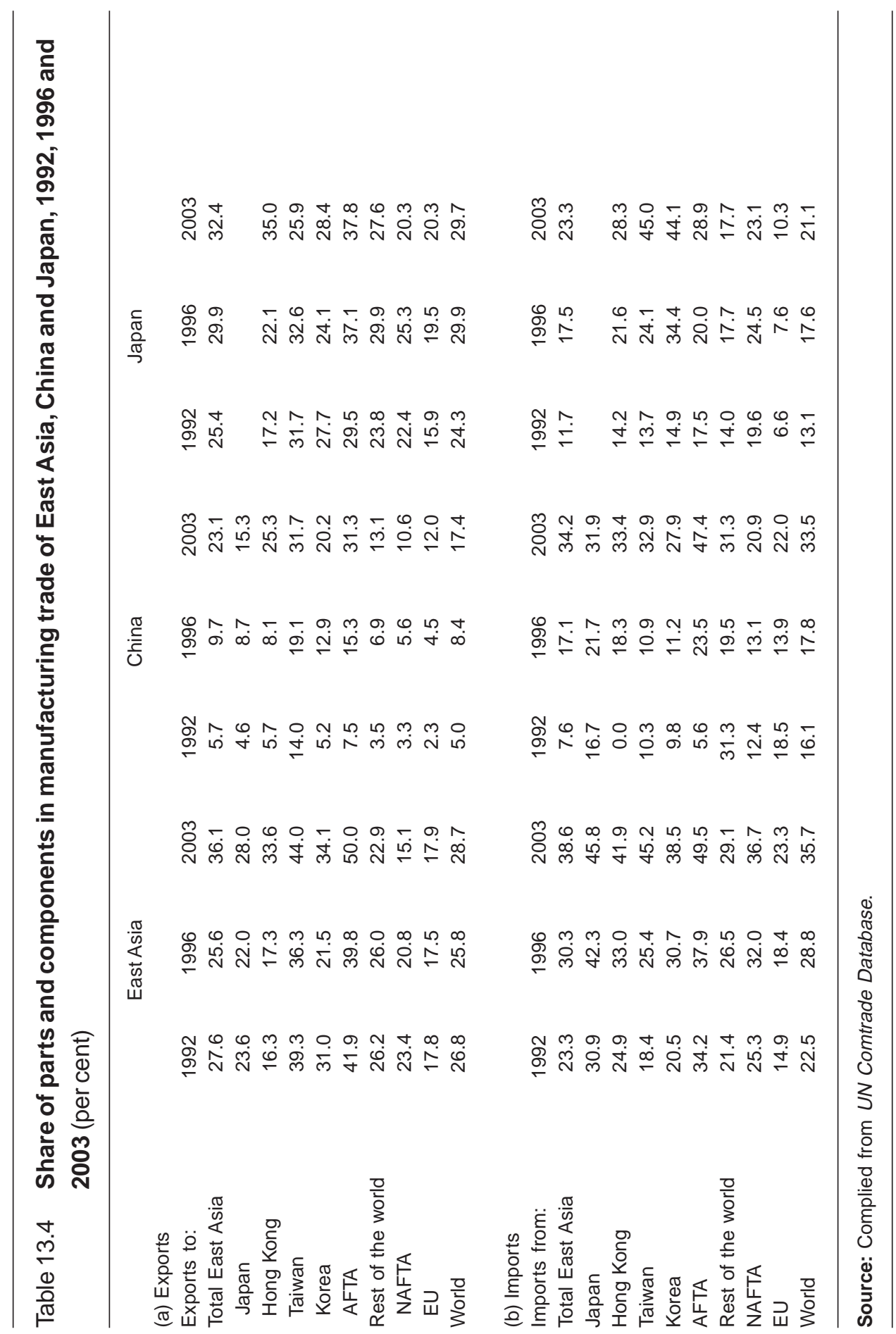


The share of components in regional exports of China increased from 5.7 per cent in 1992 to over 23 per cent in 2003. On the import-side, the increase was even faster between the two years, from 7.6 per cent to 34.2 per cent. By 2003, intra and inter-regional difference in parts and component shares in Chinese imports was broadly similar to the overall East Asian patterns. However, on the export side the shares were much lower both in intra and extra-regional exports. This difference reflects the increasingly important role of China as a final product assembler for advanced-country markets using middle-products procured from the region. For the same reason there is a clear difference between China and Japan in terms of the relative importance of components in export and import flows. China's parts and component shares on the export side are notably smaller across all trading partner countries/regions compared to that of Japan, whereas more or less the reverse pattern holds on the import side.

The growing importance of components in intra-regional trade points to the need for separating final trade from trade in components in order to gain a clear understanding of the on-going process of China's trade integration and its implications for other countries in the region. Table 5 presents data for 1992, 1996 and 2003 on percentage shares of East Asia in China's manufacturing trade with this disaggregation.

The shares of Chinese imports of total manufacturing coming from East Asia increased from 64.3 per cent in 1992 to 76.2 per cent in 2003. This increase was dominated by components. The regional share of total imports of components increased from 30.3 per cent to 77.7 per cent between these two years, compared to a mild increase in final imports from 70.5 per cent to 75.4 per cent. Parts and component imports accounted for over 90 per cent of the total increment in total Chinese regional imports between 1992 and 2003. Japan has continued to be the major regional source country. But when it comes to imports of components, there has been a notable diversification of source countries (Figure 13.2). The most notable development is the rapid growth of the combined share of AFTA, from a mere 1 per cent in 1992 to 19.3 per cent 2003. Within AFTA, import shares of Malaysia and the Philippines have increased at a faster rate compared to that of Singapore. By 2003, Malaysia's share in total Chinese imports of components stood at 8 per cent compared to Singapore's of 3.5 per cent. Import shares of Taiwan and Korea also have increased persistently. However, the share of Hong Kong has declined as much of manufacturing activities carried out by Hong Kong businesses relocated to Mainland China. Overall, the data clearly suggest that China's trade integration through fragmentation trade is not predominantly a phenomenon limited to Greater 
China (or the 'China Circle', see Naughton 1997). The procurement network has rapidly expanded to cover other countries in the region.

On the exports side, the aggregate regional share has declined persistently for total manufacturing as well as the two sub-categories of components, and final goods. Overall, China's evolving export patterns exhibit a clear extra-regional bias (the degree of which has increased over the year), in contrast to greater regional integration on the import side. However, the aggregate figure, being dominated by the dramatic decline in exports to Hong Kong, camouflages some noteworthy differences among individual countries/country groups. For instance, export share of AFTA has increased persistently throughout the period under study reflecting the growing importance of two-way trade in components. The share of AFTA in total component exports from China increased from 4.8 in 1992 to 11.2 per cent in 2003.

A comparison of data reported in Tables 13.5 and 13.6 reveals some noteworthy differences between intra-regional trade patterns of China and Japan. The share of intra-regional imports in manufacturing imports of Japan has increased over the year. The increase in the share of parts and components is particularly noteworthy. However, overall the degree of regional bias in Japanese imports is small compared to China. On the export side, Japan's regional shares in final goods have increased, in contrast to the persistent trend noted above for China. However, the regional share of China's component exports is much larger and growing faster (when the exceptional case of Hong Kong is excluded) compared to that of Japan. This reflects China's rising role as a key player in regional production networks.

From 1997 China has maintained a net importing position (a widening trade deficit) with the region. If Hong Kong is excluded the average deficit over the past six years would have been even larger (Table 13.7, Figure 13.3). The prime source of the widening deficit has been increasing reliance on countries in the region for sourcing parts and components for fuelling booming domestic final good assembly activities. Net parts and components trade with the region increased persistently from about US $\$ 2$ billion in 1997 to over US $\$ 50$ billion in 2003. The import position in final goods trade also has recorded a mild but persistent increase from 1999 onwards. China's net trade position in favour of the region has in fact widened in recent years. By contrast, Japan has persistently recorded a large trade surplus, reflecting the heavy involvement of Japanese companies in overseas assembly activities to maintain their competitiveness in final trade in third country markets. Put simply, Japan's trade relations with the rest of East Asia is predominantly in the form of using the region as an assembly base for meeting demand in the region and, more importantly for exporting to the rest of the world. 
Figure 13.2 China's regional manufacturing trade (shares in total trade)

(i ) Parts and components

(a) Exports

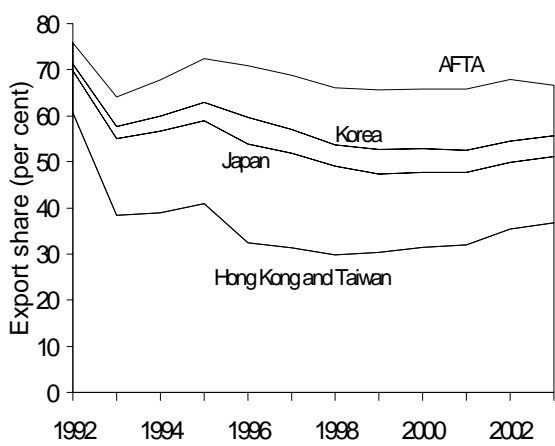

(ii) Final manufacturing

(a) Exports

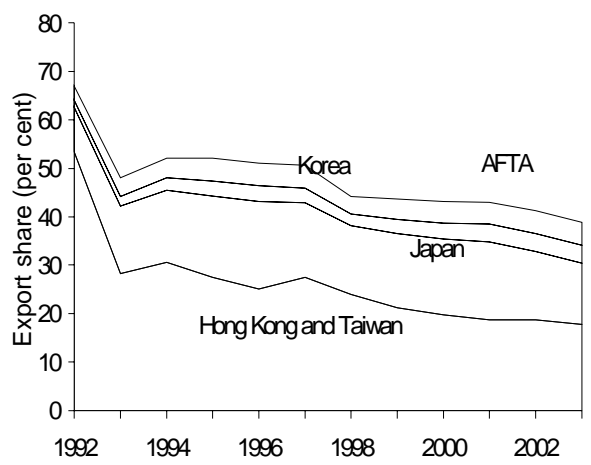

Total manufacturing

(a) Exports

80

宽 60

ఏ్ర 50

ฮั 40

$\frac{\pi}{5}$
$\frac{\pi}{5} 30$
$\frac{7}{2}$
$\frac{0}{x} 20$

永 10

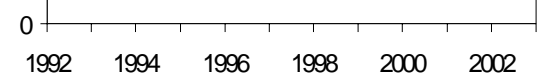

(b) Imports

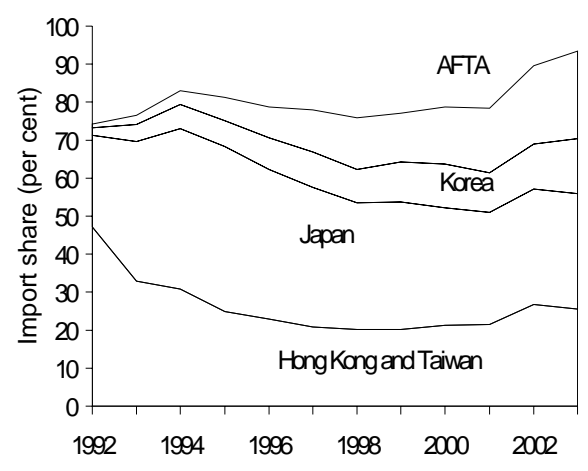

(b) Imports

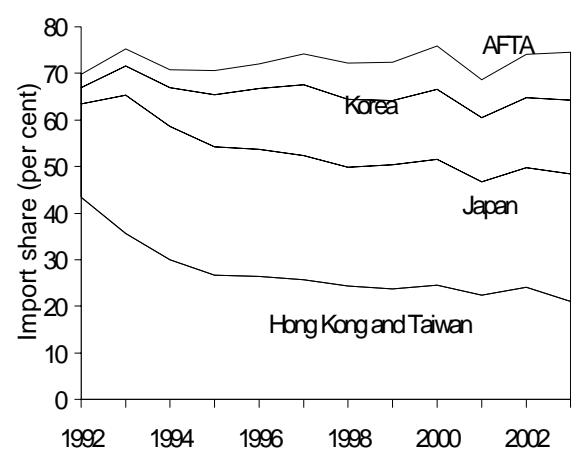

(b) Imports

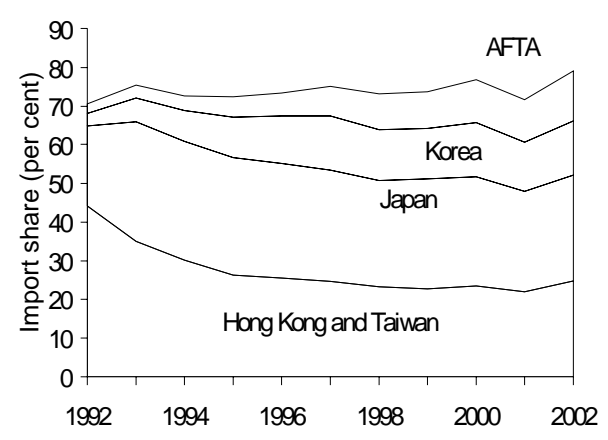

Source: Compiled from UN Comtrade Database. 
Table 13.5 Share of East Asia in Chinese exports and imports of manufactured goods, 1992, 1996 and 2003 (per cent)

\begin{tabular}{|c|c|c|c|c|c|c|}
\hline & & Exports & & & Imports & \\
\hline & 1992 & 1996 & 2003 & 1992 & 1996 & 2003 \\
\hline (a) Parts and componer & & & & & & \\
\hline Japan & 8.6 & 18.8 & 11.1 & 24.2 & 35.0 & 25.3 \\
\hline Hong Kong & 61.0 & 22.9 & 27.0 & 5.3 & 8.6 & 4.2 \\
\hline Taiwan & 1.7 & 3.7 & 3.6 & 5.3 & 10.4 & 16.9 \\
\hline Republic of Korea & 1.5 & 5.4 & 4.3 & 1.9 & 7.6 & 12.2 \\
\hline AFTA & 4.8 & 10.4 & 11.2 & 0.9 & 7.5 & 19.3 \\
\hline Indonesia & 0.7 & 1.4 & 0.8 & 0.0 & 0.1 & 0.5 \\
\hline Malaysia & 1.0 & 2.4 & 3.8 & 0.1 & 1.7 & 7.9 \\
\hline Philippines & 0.3 & 0.7 & 1.1 & 0.0 & 0.3 & 4.7 \\
\hline Singapore & 2.4 & 5.2 & 3.9 & 0.7 & 4.2 & 3.5 \\
\hline Thailand & 0.5 & 0.8 & 1.6 & 0.1 & 1.3 & 2.7 \\
\hline Vietnam & 0.1 & 0.3 & 0.3 & .. & .. & .. \\
\hline $\begin{array}{l}\text { Total East Asia } \\
\text { (b) Final goods }\end{array}$ & 77.6 & 61.1 & 57.2 & 30.3 & 69.1 & 77.7 \\
\hline Japan & 9.3 & 18.1 & 13.0 & 20.4 & 27.3 & 27.2 \\
\hline Hong Kong & 52.7 & 23.7 & 16.8 & 33.2 & 8.3 & 4.0 \\
\hline Taiwan & 0.6 & 1.4 & 1.6 & 10.6 & 18.4 & 17.4 \\
\hline Korea & 1.4 & 3.3 & 3.5 & 3.4 & 13.0 & 15.8 \\
\hline AFTA & 3.1 & 5.2 & 5.2 & 2.9 & 5.3 & 10.8 \\
\hline Indonesia & 0.4 & 0.7 & 0.8 & 1.5 & 1.1 & 1.5 \\
\hline Malaysia & 0.5 & 0.7 & 0.9 & 0.5 & 1.4 & 2.3 \\
\hline Philippines & 0.2 & 0.5 & 0.5 & 0.1 & 0.1 & 1.0 \\
\hline Singapore & 1.3 & 2.2 & 1.6 & 0.6 & 1.8 & 3.5 \\
\hline Thailand & 0.7 & 0.7 & 0.7 & 0.2 & 0.9 & 2.4 \\
\hline Vietnam & 0.1 & 0.5 & 0.5 & .. & .. & 0.2 \\
\hline $\begin{array}{l}\text { Total East Asia } \\
\text { (c) Total manufacturing }\end{array}$ & 67.2 & 51.9 & 40.1 & 70.5 & 72.4 & 75.4 \\
\hline Japan & 9.2 & 18.2 & 12.7 & 20.5 & 28.7 & 26.6 \\
\hline Hong Kong & 53.1 & 23.7 & 18.5 & 27.9 & 8.4 & 4.3 \\
\hline Taiwan & 0.6 & 1.6 & 2.0 & 9.9 & 17 & 17.3 \\
\hline Korea, Rep of & 1.4 & 3.5 & 3.7 & 3.1 & 12.1 & 14.6 \\
\hline AFTA & 3.2 & 5.7 & 6.2 & 2.6 & 5.7 & 13.7 \\
\hline Indonesia & 0.4 & 0.7 & 0.8 & 1.1 & 0.7 & 1.0 \\
\hline Malaysia & 0.5 & 0.9 & 1.4 & 0.4 & 1.3 & 3.9 \\
\hline Philippines & 0.2 & 0.5 & 0.6 & 0.1 & 0.1 & 2.1 \\
\hline Singapore & 1.4 & 2.4 & 2.0 & 0.6 & 2.0 & 3.1 \\
\hline Thailand & 0.6 & 0.7 & 0.8 & 0.2 & 0.9 & 2.3 \\
\hline Vietnam & 0.1 & 0.5 & 0.5 &.. &.. & 0.1 \\
\hline Total East Asia & 67.6 & 52.7 & 43.0 & 64.3 & 71.8 & 76.2 \\
\hline
\end{tabular}

Source: Complied from UN Comtrade Database. 


\section{Conclusion}

There is clear evidence that fragmentation-based specialisation has become an integral part of the economic landscape of East Asia. Trade in components has been expanding more rapidly than conventional final-goods trade. The degree of dependence on this new form of international specialisation is proportionately larger in East Asia than in North America and Europe.

Over the past decade or so, China has been rapidly integrating into the regional production networks. This development is an important counterpoint to the popular belief that China's global integration would crowd out other countries' opportunities for international specialisation. The estimates presented in this paper support our hypothesis that, in a context where fragmentation-based trade is expanding rapidly, standard trade flows analysis can lead to an understatement of the trading significance of China in the process of economic integration through trade. China's imports of components from East Asia have grown rapidly, in line with rapid expansion of manufacturing exports mostly to North America and the European Union. Reflecting this evolving pattern of international specialisation, China has run a persistent and widening net trade position with East Asia (excluding Japan). By contrast Japan has maintained a persistent, net surplus in its regional trade. The surplus has, however, marginally narrowed in recent years because of growing assembly imports from the region, from China in particular to Japan.

Increasing intra-regional economic interdependence in East Asia through international product fragmentation does not, however, mean that the process has contributed to lessoning the regions' dependence on the global economy. The region's growth dynamism based on this new form of specialisation depends inexorably on its extra-regional trade in final good, and this dependence has in fact increased over the years. While the growing importance of China both as a regional exporter and importer has begun to change the picture in recent years, extra-regional trade is likely to remain the engine of growth of the region in the foreseeable future. Growing trade in components has made the East Asian region increasingly reliant on extra-regional trade for its growth dynamism.

Is China's reliance on other countries in the region for sourcing components for its burgeoning electronics and electrical industries a structural feature of the ongoing process of its rapid economic integration? Or is it a passing phenomenon which will last only until China develops its own domestic production capabilities? Some analysts (for example, Lall and Albaladejo 2004) allude to the latter possibility, arguing that China has the potential to build a strong electronics industry based predominantly on locally produced components within its boundaries, combining 
Table 13.6 Share of East Asia in total Japanese exports and imports, 1992, 1996 and 2003

\begin{tabular}{|c|c|c|c|c|c|c|}
\hline & & Exports & & & Imports & \\
\hline & 1992 & 1996 & 2003 & 1992 & 1996 & 2003 \\
\hline (a) Parts and compone & & & & & & \\
\hline China & 1.4 & 2.9 & 12.3 & 2.3 & 6.9 & 18.3 \\
\hline Hong Kong & 4.3 & 4.3 & 7.4 & 2.2 & 1.5 & 0.7 \\
\hline Taiwan & 7.7 & 6.4 & 5.7 & 6.3 & 8.3 & 12.4 \\
\hline Republic of Korea & 5.7 & 5.3 & 6.5 & 9.3 & 11.6 & 12.8 \\
\hline AFTA & 14.0 & 22.3 & 15.4 & 13.7 & 17.4 & 21.7 \\
\hline Indonesia & 1.3 & 1.8 & 1.7 & 0.5 & 1.0 & 1.4 \\
\hline Malaysia & 3.6 & 4.9 & 3.1 & 3.3 & 4.2 & 5.6 \\
\hline Philippines & 1.2 & 2.6 & 3.0 & 1.6 & 3.8 & 5.7 \\
\hline Singapore & 4.8 & 5.6 & 3.6 & 3.9 & 5.5 & 4.1 \\
\hline Thailand & 3.2 & 4.0 & 4.0 & 4.5 & 2.9 & 4.9 \\
\hline Vietnam & 0.0 & 0.1 & 0.3 & 0.0 & 0.0 & 0.3 \\
\hline $\begin{array}{l}\text { Total East Asia } \\
\text { (b ) Final goods }\end{array}$ & 33.3 & 41.2 & 47.2 & 33.4 & 45.8 & 65.9 \\
\hline China & 3.7 & 5.8 & 11.4 & 12.4 & 19.8 & 34.6 \\
\hline Hong Kong & 6.6 & 6.5 & 5.8 & 1.8 & 1.1 & 0.5 \\
\hline Taiwan & 5.3 & 5.6 & 6.8 & 6.0 & 5.6 & 4.1 \\
\hline Korea & 4.7 & 7.2 & 6.9 & 8.0 & 4.8 & 4.3 \\
\hline AFTA & 10.8 & 16.1 & 10.7 & 9.8 & 14.8 & 14.3 \\
\hline Indonesia & 1.6 & 2.3 & 1.4 & 2.5 & 2.8 & 2.7 \\
\hline Malaysia & 1.9 & 2.9 & 1.8 & 1.8 & 3.7 & 3.1 \\
\hline Philippines & 1.0 & 1.8 & 1.4 & 0.7 & 1.4 & 2.0 \\
\hline Singapore & 3.4 & 4.5 & 2.6 & 1.6 & 2.7 & 1.5 \\
\hline Thailand & 2.7 & 4.3 & 2.8 & 3.1 & 3.6 & 3.8 \\
\hline Vietnam & 0.2 & 0.4 & 0.6 & 0.1 & 0.6 & 1.1 \\
\hline $\begin{array}{l}\text { Total East Asia } \\
\text { (c) Total manufacturing }\end{array}$ & 31.2 & 41.2 & 41.6 & 38.1 & 46.1 & 57.8 \\
\hline China & 3.2 & 4.9 & 11.7 & 11.1 & 17.5 & 31.2 \\
\hline Hong Kong & 6.1 & 5.8 & 6.3 & 1.8 & 1.2 & 0.5 \\
\hline Taiwan & 5.9 & 5.8 & 6.5 & 6.0 & 6.1 & 5.8 \\
\hline Korea & 5.0 & 6.6 & 6.7 & 8.2 & 6.0 & 6.1 \\
\hline AFTA & 11.6 & 18 & 12.1 & 10.3 & 15.3 & 15.8 \\
\hline Indonesia & 11.6 & 17.7 & 12.3 & 2.2 & 2.4 & 2.3 \\
\hline Malaysia & 1.6 & 2.2 & 1.5 & 1.9 & 3.6 & 3.5 \\
\hline Philippines & 2.3 & 3.7 & 2.2 & 0.8 & 1.7 & 2.7 \\
\hline Singapore & 1.0 & 2.1 & 1.9 & 1.8 & 3.0 & 1.9 \\
\hline Thailand & 3.7 & 5.1 & 2.9 & 3.1 & 3.3 & 3.8 \\
\hline Vietnam & 2.8 & 4.4 & 3.2 & 0.1 & 0.4 & 0.9 \\
\hline Total East Asia & 31.6 & 41.2 & 43.3 & 37.4 & 46.1 & 59.5 \\
\hline
\end{tabular}

Source: Complied from UN Comtrade Database. 
Table 13.7 China and Japan: net trade with East Asia, 1992, 1996 and 2003 (Export minus imports as a percentage of exports)

\begin{tabular}{|c|c|c|c|c|c|c|}
\hline \multirow{2}{*}{$\begin{array}{l}\text { Imports } \\
\text { To: }\end{array}$} & \multicolumn{3}{|c|}{ China } & \multicolumn{3}{|c|}{ Japan } \\
\hline & 1992 & 1996 & 2003 & 1992 & 1996 & 2003 \\
\hline \multicolumn{7}{|c|}{ (a) Parts and components } \\
\hline Japan & -718.6 & -284.2 & -297.7 &.. &.. &.. \\
\hline China & .. & .. & .. & 72.5 & 25.8 & 42.2 \\
\hline Hong Kong & 100.0 & 22.4 & 74.0 & 91.2 & 89.2 & 96.3 \\
\hline Taiwan & -1101.8 & -483.7 & -729.2 & 84.5 & 59.0 & 14.0 \\
\hline Korea & -324.5 & -190.3 & -399.1 & 69.0 & 31.8 & 22.2 \\
\hline AFTA & 38.6 & -48.8 & -202.7 & 81.6 & 75.6 & 44.8 \\
\hline $\begin{array}{l}\text { Total East Asia } \\
\text { (b) Final manufa }\end{array}$ & -29.1 & -133.2 & -138.0 & 81.0 & 65.3 & 45.4 \\
\hline East Asia & 4.9 & -21.4 & -37.5 & 51.2 & 30.2 & 14.1 \\
\hline Japan & -98.6 & -31.4 & -53.5 & .. & .. &.. \\
\hline China & .. & .. &.. & -33.0 & -112.5 & -88.0 \\
\hline Hong Kong & 43.0 & 69.5 & 82.4 & 89.1 & 88.9 & 95.0 \\
\hline Taiwan & -1615.7 & -1021.2 & -686.1 & 55.0 & 37.7 & 63.3 \\
\hline Korea & -112.0 & -239.4 & -226.8 & 32.3 & 58.7 & 60.9 \\
\hline AFTA & 15.9 & 12.6 & -53.2 & 63.6 & 42.7 & 17.3 \\
\hline $\begin{array}{l}\text { Total East Asia } \\
\text { (c ) Total manuf }\end{array}$ & 4.9 & -21.4 & -37.5 & 51.2 & 30.2 & 14.1 \\
\hline Japan & -127.3 & -53.2 & -90.9 & .. & .. & .. \\
\hline China & .. & .. & .. & -21.9 & -88.1 & -47.1 \\
\hline Hong Kong & 46.2 & 65.7 & 80.2 & 89.4 & 89.0 & 95.5 \\
\hline Taiwan & -1543.5 & -918.7 & -699.8 & 64.4 & 44.6 & 50.5 \\
\hline Korea & -122.9 & -233.1 & -261.7 & 42.5 & 52.2 & 49.9 \\
\hline AFTA & 17.6 & 3.2 & -100.0 & 68.9 & 54.9 & 27.7 \\
\hline Total East Asia & 3.0 & -32.2 & -60.8 & 58.8 & 40.7 & 24.3 \\
\hline
\end{tabular}

Source: Complied from UN Comtrade Database. 
a high export competitiveness with an import substitution policy for an enormous domestic market. However, China's industrial transformation over the past oneand-a-half decades has not yielded any indication of this happening. We have seen that the net trade deficit in components has persistently widened during this period. It seems that firms involved in vertically integrated global industries tend to rely on international networks of production, which embrace difference territories and different forms of cooperation to optimise their competitiveness. Because of technological complexities and intrinsic country-specific cost advantages nations are becoming specialised in specific activity in the value chain and in certain kinds of products. Moreover, over a long period of time many MNEs (particularly United States-based MNEs) have significantly upgraded technical capabilities of their regional production networks in East Asia and assigned global production responsibilities to affiliates located in more mature countries (Singapore and Taiwan in particular). Naturally country risk considerations would have a much greater bearing on any corporate decision to deviate from these well-established global practices compared to simple relative cost considerations.

Is the new-found fondness in China and other East Asian countries for free trade agreements (FTAs) consistent with the objective of maximising gains from the ongoing process of international production fragmentation? Trade in components and final assembly is more sensitive to tariff changes than final trade (or total trade as captured in published trade data) (Yi 2003). Normally a tariff is incurred each time a goods-in-process cross a border. Consequently, with one percentage point reduction in tariff, the cost of production of a vertically-integrated good declines by a multiple of this initial reduction, in contrast to a one per cent decline in the cost of a regular traded good. Moreover, tariff reduction may also make more profitable goods that were previously produced entirely in one country and have now become vertically specialised. Consequently, in theory, the trade-stimulating effect of FTA would be higher for parts and component trade than for normal trade, other things remaining unchanged. However, in reality, much would depend on the nature of 'rules or origin' (ROOs) built into FTAs (Garnaut 2003). Trade distorting effects of ROOs are presumably more detrimental to fragmentation-based trade than for conventional final goods trade, because of the inherent difficulties involved in defining the 'product' for duty exception and the transaction costs associated with the bureaucratic supervision of the amount of value-added in production coming from various sources. Moreover, maintaining barriers to trade against non-members (while allowing free trade among members) can thwart 'natural' expansion of fragmentation of trade across countries. Formation of FTAs would therefore simply result in substituting for the existing tariff concessions rather that generating new 


\section{Figure 13.3 China and Japan:Trade with East Asia ${ }^{1}$ (US\$ billon)}

(i ) Parts and components

(a) China

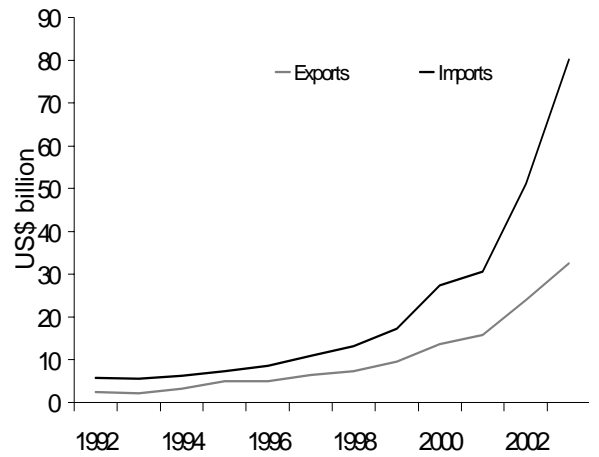

(ii) Final manufacturing

(a) China

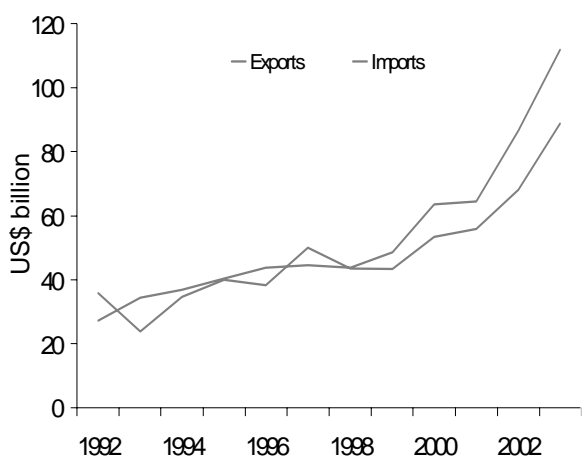

Total manufacturing

(a) Exports

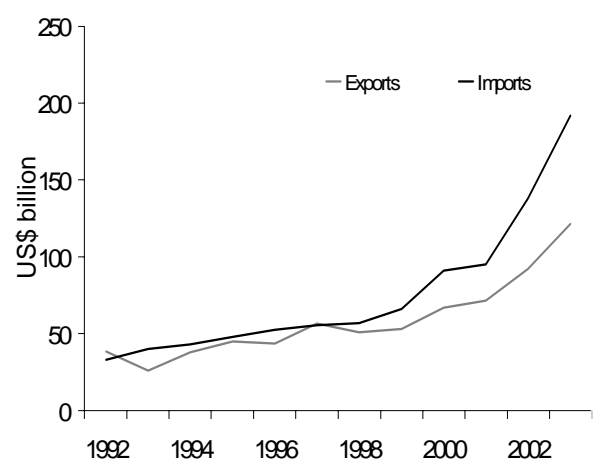

(b) Japan
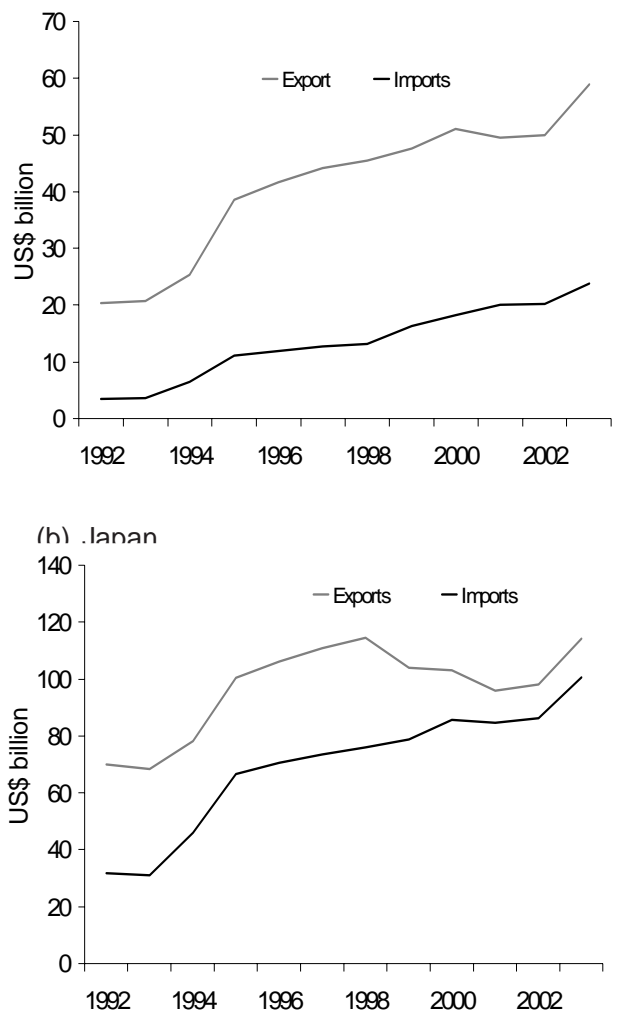

(b) Japan

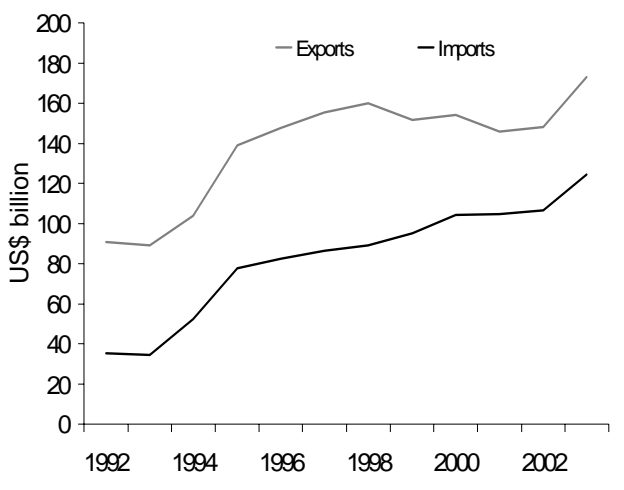

Note: ${ }^{1}$ East Asia excluding China and Japan

Source: Compiled from UN Comtrade Database. 
incentives for fragmentation trade. Thus, in terms of opportunities for trade expansion through international product fragmentation, the ideal policy choice appears to be multilateral liberalisation through the WTO process; the ongoing process of product fragmentation seems to have strengthened the case for a global, rather than a regional, approach to trade and investment policymaking.

\section{Notes}

1 Alternative terms include 'vertical specialisation', 'slicing the value chain', 'disintegration of production' and 'international production sharing' and 'outsourcing'.

2 For instance 'television tubes' were not separable from 'TVc' and ' computer processors' were lumped together with 'computers'.

3 The list is available in Athukorala (2003), Appendix A-5.

4 Much of Hong Kong's component trade relates to production fragmentation-based activities in the Mainland China and most (Freenstra et al. 1999).

\section{References}

Ahearne, A.G., Fernald, J.G., Loungani, P. and Schindler, J.W., 2003. China and emerging Asia: comrades or competitors?, International Finance Discussion Paper No. 789, Board of Governors of the Federal Reserve System, New York. Arndt, S. and Kierzkowski, H. (eds.), 2001. Fragmentation: new production patterns in the world economy, Oxford University Press, New York.

Athukorala, P., 2003. Production fragmentation and trade patterns in East Asia, Trade and Development Discussion Paper 2003/21, Division of Economics, Research School of Pacific and Asian Studies, The Australian National University, Canberra.

_- (forthcoming). 'Production fragmentation and trade patterns in East Asia', Asian Economic Papers.

_ and Yamashita, N., (forthcoming). 'Production fragmentation and trade Integration: East Asia in a global context', North American Journal of Economics and Finance.

Borrus, M., 1997. 'Left for dead: Asian production networks and the revival of USE electronics', in Barry Naughton (Ed.), The China Circle: economics and technology in the PRC, Taiwan and Hong Kong, Brookings Institution Press, Washington, DC:139-63.

_- Earnst, D. and Haggard, S., 2000. International Production Networks in Asia: Rivalry or Riches?, Routledge, London.

Brown, C. and Linden, G., 2005. 'Offshoring in the semiconductor industry: a 
historical perspective', in Lael Brainard and Susan M. Collins (eds), Brookings Trade Forum:2005, Brookings Institution Press, Washington, DC.

Eichengreen, B., Rhee, Y. and Tong, H., 2004. The impact of China on the exorts of other Asian countries, National Bureau of Economic Research (NBER) Working Paper 10768, NBER, Massachussets.

Feenstra, R.C., Hai, W., Woo, W.T. and Yao, S., 1999. 'Discrepancies in international trade data: an application to China-Hong-Kong entrepot trade', American Economic Review, 87(2):338-43.

Lardy, N.R., 2002. Integrating China into the Global Economy, Brookings Institution Press, Washington, DC.

$\mathrm{Ng}, \mathrm{F}$. and Yeats, A., 2001. 'Production sharing in East Asia: who does what for whom, and why?', in L. K. Cheng and H. Kierzkowski (eds), Global Production and Trade in East Asia, Kluwer Academic Publishers, Boston:63-109.

Garnaut, R., 2003. 'Australia and Japan: time to be important to each other again', address to the Australia-Japan Business Committee conference, Kyoto, 5 October.

Grossman, G.M. and Helpman, E., 2005. 'Outsourcing in a global economy', Review of Economic Studies, 72(1):135-59.

International Monetary Fund (IMF), 2004. 'China's emergence and its impact on the global economy', World Economic Outlook, International Monetary Fund Washington, DC:82-102

Jones, R.W., 2000. Globalization and the Theory of Input Trade, MIT Press, Cambridge.

- and Kierzkowski, H., 2001. 'Globalization and the consequences of international fragmentation', In R. Dornbusch, G. Calvo and M. Obstfeld (eds), Money, Factor Mobility and Trade: the festschrift in honor of Robert A. Mundell, Press, Cambridge:365-81.

- and Chen Lurong, 2005. 'What does the evidence tell us about fragmentation and outsourcing', International Review of Economics and Finance, 14(3):30516.

Kaminski, B. and Ng, F., 2004. 'Production disintegration and integration of central Europe into global markets', International Review of Economics and Finance, 14(3):377-90.

Kierzkowski, H., 2001. 'Joining the global economy: experience and prospects of the transition economies', in S.W. Arndt \& H. Kierzkowski (eds), Fragmentation: new production patterns in the world economy, Oxford University Press, Oxford: 231-53. 
Lall, S. and Albaladejo, M., 2004. 'China's competitive performance: a threat to East Asian manufactured exports?', World Development, 32(9):1441-66.

Lemoine, F. and Ünal-Kesenci, D., 2004. 'Assembly trade and technology transfer: the case of China', World Development, 32(5):829-50.

McKendrick, D.G., Doner, R.F. and Haggard, S., 2000. From Silicon Valley to Singapore: location and competitive advantage in the hard disk drive industry., Stanford University Press, Stanford.

Naughton, B., 1997. 'The emergence of China circle', in Barry Naughton (ed.), The China Circle: economics and technology in the PRC, Taiwan and Hong Kong, Brookings Institution Press, Washington, DC:3-37.

_ 1999. 'The global electronics revolution and China's technology policy', NBR Analysis, 10(2):5-28.

Rangan, S. and Lawrence, R., 1999. A prism on globalization, Brookings Institution Press, Washington, DC.

Yi, K., 2003. 'Can vertical specialization explain the growth of world trade', Journal of Political Economy, 111(1):52-102. 